\title{
COPPER-RESISTANT MICROORGANISMS ISOLATED FROM ANTARCTIC ISLAND GALINDES
}

\author{
N.A. Matveeva, G.O. Tashyreva, O.B. Tashyrev \\ Institute of Microbiology and Virology of National Academy of Science of Ukraine, \\ Department of general and soil microbiology, Department of physiology of gas-oxidizing microorganisms, E- mail: \\ joyna@i.com.ua, tach@i.com.ua.
}

\begin{abstract}
The copper-resistant microorganisms were isolated from soils of Antarctic island Galindes. It was shown that these microorganisms can grow on the medium with concentration of $\mathrm{Cu}^{2+}$ ions $1000-3000 \mathrm{ppm}$.

Key words: resistance to high concentrations of copper, Antarctic microorganisms.

Антарктические медьрезистентные микроорганизмы острова Галиндез. Н.А.Матвеева, А.А.Таширева, А.Б.Таширев. Изучены микробные ценозы антарктического острова Галиндез и выделены культуры микроорганизмов, которые могут расти на среде с содержанием ионов меди до 1000-3000 мг/л.
\end{abstract}

Антарктичні мідьрезистентні мікроорганізми острова Галіндез. Н.А.Матвєєва, Г.О.Таширева, О.Б.Таширев. Досліджено мікробні ценози антарктичного острова Галіндез та виділено культури мікроорганізмів, що ростуть на середовищі зі вмістом іонів міді 1000 -3000 мг/л.

\section{Introduction}

Islands of Argentine archipelago including Antarctic island Galindes consist of magmatic rocks, that contain high concentrations of the heavy metals. Because of the physics, chemical and biological destruction this metals move to the environment. The high maintenance of the toxic heavy metals, including copper, can be result of the appearance of $\mathrm{Cu}^{2+}$-resistant microorganisms. The objective of our study was to find microorganisms resistant to high concentrations of $\mathrm{Cu}^{2+}$ in soils of Antarctic island Galindes.

\section{Materials and methods}

Getting samples $-25^{\circ} \mathrm{C}$

Samples of soil were selected on Antarctic island in 2002 year. They were frozen and stored under the temperature

Inoculate preparation

$1 \mathrm{~g}$ of sample was homogenized and suspended into $100 \mathrm{ml}$ of sterile saline solution $(0.9 \% \mathrm{NaCl})$ and vigorously shaken for 2 hour. $20 \mu \mathrm{l}$ of suspension were put in Petri dishes on the MPA media surface with the $\mathrm{Cu}^{2+}$ concentration 200-3000 ppm.

Preparation of $\mathrm{Cu}^{2+}$ solution

For preparation of $\mathrm{Cu}^{2+}$ solution we used chemical pure $\mathrm{CuSO}_{4}$ and suspended it in sterile distillate water. Solution was sterilized by boiling $30 \mathrm{~min}$., than cooled to $25^{\circ} \mathrm{C}$ and added to nutrient medium to final concentration $200-3000$ ppm of $\mathrm{Cu}^{2+}$.

\section{Results and discussions}

Cooper is the chemical element which is present in soils in microquantities [5]. It is necessary in a small quantities for the formation and function of ferments, vitamins and antibiotics in microbial cells. [1]. Increasing of cooper concentration in nutrient medium cause growth inhibition and in high concentration is lethal for the most soil microorganisms [2]. So, ions of $\mathrm{Cu}^{2+}$ that is a toxic heavy metal can stimulate growth of soil microorganisms in a small

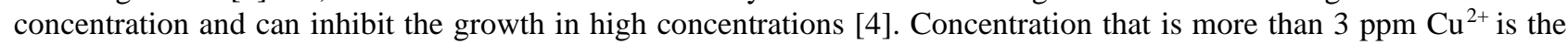
lethal concentrations for soil microorganisms [3].

Investigation of microorganisms isolated from Antarctic islands conducted during many years but the cooperresistant microorganisms was not discover. The objective of our study was to find $\mathrm{Cu}^{2+}$-resistant microorganisms in

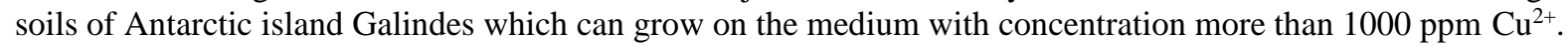

In order to investigate the growth of Antarctic islands microorganisms the $20 \mu 1$ of suspension were put in Petri dishes on the MPA media surface without the $\mathrm{Cu}^{2+}$ (control). It has been shown that there are 4 types of colonies: a) small yellow 1-2 mm; b) white prominent 3-4 mm; c) large, plane with wavy border near $30 \mathrm{~mm}$; d) small pink 1-2 mm (table 1). 
Growth the microorganisms on the MPA medium

\begin{tabular}{|c|c|c|c|c|}
\hline Types of colonies & Color & Shape & Diameter, $\mathrm{mm}$ & Border \\
\hline 1 & yellow & round & $1-2$ & even \\
\hline 2 & white & round & $3-4$ & even \\
\hline 3 & white & plane & till 30 & wavy \\
\hline 4 & pink & round & $1-2$ & even \\
\hline
\end{tabular}

The colonies of type 2 (white prominent) appeared at first, their quantity was till 300 per dish. Then appeared small yellow, large plane with wavy border and small pink colonies (Fig. 1) (Fig. 1-3 see color paste).

In order to discover the cooper-resistant microorganisms the $20 \mu$ l of suspension were put in Petri dishes on the MPA medium surface with the $\mathrm{Cu}^{2+}$ concentration 200-1000 ppm. It has been shown that there are 4 types of colonies: 1)small yellow 1-2 mm;2) white prominent 3-4 mm;3) large, plane with wavy border near $30 \mathrm{~mm}$; 4) small pink 1-2 $\mathrm{mm}$ (tabl.2, fig. 2).

Growth of microorganisms on the MPA medium with 200-1000 $\mathrm{ppm} \mathrm{Cu}^{2+}$

\begin{tabular}{|c|c|c|c|c|}
\hline Types of colonies & Color & Shape & Diameter, $\mathrm{mm}$ & Border \\
\hline 1 & yellow & round & $1-2$ & even \\
\hline 2 & white & round & $3-4$ & even \\
\hline 3 & white & plane & till 30 & wavy \\
\hline 4 & pink & round & $1-2$ & even \\
\hline
\end{tabular}

Investigation have been shown that in Antarctic soil there are the cooper-resistant microorganisms and

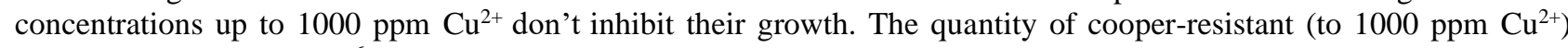
microorganisms was $1 \cdot 10^{6}$ cells per $1 \mathrm{~g}$ of soil.

During the cultivation 9 selected strains were found their ability to grow under the cooper concentration 1000-3000 ppm (Table. 3).

Strains XЧ, X7, ХП, ХБ were able to grow on the medium supplemented $\mathrm{Cu}^{2+} 2000 \mathrm{ppm}$, strain $\mathrm{X} 7-3000 \mathrm{ppm}$ of cooper. Such concentration is 1000 times higher then the lethal for the major part soil microorganisms.

The concentration up to $800 \mathrm{ppm}$ had no influence on the growth of cooper-resistant microorganisms (Fig.3). This testifies that there are the adaptation mechanisms, which neutralize toxic cooper influence on the microbial cells.

Table 3.

Resistance of strains XЧ, X7, XП, XБ at $\mathrm{Cu}^{2+}$ concentration up to $3000 \mathrm{ppm}$.

\begin{tabular}{|l|c|c|c|c|c|c|c|c|}
\hline & 0 & 200 & 600 & 1000 & 1500 & 2000 & 2500 & 3000 \\
\hline $\mathrm{XЧ}$ & + & + & + & + & + & + & + & - \\
\hline $\mathrm{X} 7$ & + & + & + & + & + & + & + & + \\
\hline $\mathrm{XП}$ & + & + & + & + & + & + & - & - \\
\hline $\mathrm{XБ}$ & + & + & + & + & + & + & - & - \\
\hline
\end{tabular}

\section{Conclusion}

The copper- super resistant microorganisms were found in soils of Antarctic island Galindes._It was shown that these microorganisms can grow on the media with the ions $\mathrm{Cu}^{2+}$ concentration $1000-3000$ ppm which is in 1000 times higher then the lethal for the most soil microorganisms. Such resistance can be the result of the high cooper concentration in Antarctic soils.

\section{References}

1. Авакян 3.А. Токсичность тяжелых металлов для микроорганизмов. Итоги науки и техники. Микробиология.Т.2.- М., ВИНИТИ.- 1973. - С.5-45.

2. Андреюк К.І., Іутинська Г.О., Антипчук А.Ф., Валагурова О.В., Козирецька В.С., Пономаренко С.П. Функціонування мікробних ценозів грунту в умовах антропогенного навантаження. К., Обереги. - 2001. - 240 с.

3. Земельні ресурси України. За ред.. В.В.Медведєва, Т.М.Лактіонової. К., Аграрна наука. - 1998. - 148 с.

4. Іутинська Г.О. Грунтова мікробіологія. К., Арістей. -2006. - 284 с.

5. Ковда В.А. Биогеохимия почвенного покрова. М., Наука. $-1985 .-263$ с. 